\title{
The Buddhist Economies of Modern Urban China
}

FRANCESCA TAROCCO

Ca' Foscari University of Venice/New York University Shanghai

ft21@nyu.edu

Keywords: Buddhism, Shanghai, merit, consumption

DOI: https://dx.doi.org/10.15239/hijbs.02.02.09

Abstract: This paper looks at the dynamic relationship between Buddhism, business, and merit in urban China, and particularly in the cities of the Lower Yangzi Delta (or Jiangnan), with a focus on Shanghai in late imperial and modern times. It argues that Shanghai residents have continued to practice Buddhism notwithstanding the widespread iconoclasm enforced by the ruling elites and the recurrent calls to end all wasteful practices associated with Chinese religion. 
he dynamic relationship between Buddhism, business, and
merit in urban China, and particularly in the cities of the Lower Yangzi Delta (or Jiangnan)—including Shanghai, Ningbo, Suzhou, Wuxi, Nanjing-is well documented. In his Sacred Economies: Buddhist Monasticism and Territoriality in Medieval China, Michael Walsh argues that 'Buddhist economic activity is not in itself surprising given the necessity of the Chinese sangha to establish themselves as a social group with societal efficacy (as with the Roman Catholic Church)'. Walsh details the economic actions that helped establish and perpetuate monastic space in the medieval period, including tea production, silver smelting and salt trading. Monastic institutions held auctions and lotteries; they were moneylenders and pawnshops. They established and run hostels and engaged in the production of silk and embroidered cloth. They made paper, ink sticks and ink stones. They also actively engaged in printing and the production of books. Importantly, whenever the wealth and power of Buddhist institutions prompted crackdowns, land confiscations and the seizure of the precious metals used for making icons, not only would monasteries recover, they sometime managed to increase their wealth. This, argues Welsh, indicates the degree to which monasteries had been integrated into the socio-economic fabric of China by the Song periods (ten to thirteenth centuries). ${ }^{1}$

By the late imperial period, Jiangnan witnessed a flowering of the commercialized economy and urban culture that has been the subject of much scholarly enquiry during in the past four decades. ${ }^{2}$ Buddhism was deeply entangled with this culture. It tended towards expansion; following the logic of merit-making, Buddhists wanted to establish as many monasteries and shrines as possible. Writing

1 See Walsh, Sacred Economies, 58-60. For the sponsorship of printed collections of texts under the leadership of local monasteries, an equally meritorious activity, see ter Haar, 'Buddhist-inspired options'.

2 Johnson, Cities of Jiangnan in Late Imperial China; Johnson, Shanghai; Dietrich, 'Cotton Culture and Manufacture'; Elvin, 'Market Towns and Waterways'; Fan, Ming Qing Jiangnan; Fan, 'Qingdai Jiangnan'. See also Li, Agricultural Development in Jiangnan. 
about gentry elites of the Ming period (1368-1644), Timothy Brook argued that they were intimately involved with Buddhism at a time when it was gaining unparalleled numbers of converts among all classes. The reading of local gazetteers demonstrates that Buddhism enjoyed plenty of economic support in the form of donations, patronage, associations and clubs. For example, the great painter Dong Qichang 董其昌 (1555-1636), a patron of the Shanghai Longhua Temple 龍華寺, raised funds toward the construction of the temple library in order for it to receive a copy of the Buddhist canon from the inner court. Dong saw himself as playing a part of in the Buddhist revival of the Wanli era (1563-1620) when 'within the four sees, reverence for the teaching of the Buddha is indeed great. From every monastery another can be seen and no one knows their number'. ${ }^{3}$ Local elites saw Buddhism as a vehicle for projecting their power and influence and as something quite distinct from the interests and will of the state. ${ }^{4}$

The late Ming period was a time of revival and revitalization of Chan Buddhism. The sixteen and seventeen centuries saw a substantial increase in temple building activities. Significant sums were poured into the repair of existing monastic structures and the construction of new ones. Since they are expensive and time consuming, temple construction projects listed in the local gazetteers can be used to measure the involvement of the population with the monastic community. In fact, in the nineteenth century, after the Taiping rebellion (1851-1864) wreaked havoc in southern China, Buddhist practitioners set out to restore and build new temples throughout Jiangnan. ${ }^{5}$ In the first half of the twentieth century, the success of the clergy in mobilizing patronage in the cities of the Yangzi River Delta was, again, quite spectacular. Today still, vast sums of money

\footnotetext{
3 Quoted in Brook, 'Xu Guangqi and His Context', 91.

4 See Brook, Praying for Power. For a study of Mount Putuo through a close reading of local gazetteers, see Bingenheimer, Island of Guanyin.

5 See Wu, Enlightenment in Dispute. See also Gregory Scott's analysis of the post-Taiping period using local gazetteers, 'Survey of Religious Reconstruction in Modern China'.
} 
are diverted to pay for restoring older temples and building new ones. Colossal statues-for instance the eighty-eight-metre-high bronze Buddha statue of Lingshan 靈山 near Wuxi-gazes over the landscape of the Greater Yangzi River metropolitan region. ${ }^{6}$

\section{Buddhism, business and merit in Shanghai}

After the abdication of the Qing Court, large quantities of capital flowed in from the hinterland to Shanghai to be deposited in both native and foreign banks. It was the 'golden age' of Chinese banking and monks too kept their ordination certificates in the safe of the Hong Kong and Shanghai Banking Corporation Limited (or HSBC). ${ }^{7}$ Thanks to the pious self-fashioning of its residents, Shanghai gradually became a vital site for Chinese Buddhist life. Money was made with Buddhism and spent for it. Shanghai residents practiced Buddhism notwithstanding the widespread iconoclasm enforced by the ruling elites and the recurrent calls to end all wasteful practices associated with religion. Several campaigns took place in the 1920s. In 1922, the so-called Great Anti-religious Society (Fei zongjiao da tongmeng 非宗教大同盟) was set up in Beijing and similar associations were founded in other parts of China. Some of these groups demanded the complete abolition of the Buddhist monastic order, a prohibition on performing rites for the dead and the elimination of gatherings to chant the sutras. Hu Shi, leader of the New Culture Movement, accused Buddhism of having caused the 'Indianization' of China, turning her into a potential victim of colonial encroachment. ${ }^{8}$ The movement to convert temples into public schools (miaochan xingxue 廟產興學) targeted not only local temples to be seized for use as public state-run schools, but also

6 For an overview of this new Buddhist site, see http://www.chinalingshan. com, accessed April 2019.

7 See Ji, A History of Modern Shanghai Banking. Welch, 'The Buddhist Career', 8.

8 Nedostup, Superstitious Regimes; Tarocco, The Cultural Practices. 
Buddhist ones. ${ }^{9}$ And yet, in the context of colonial modernity first, and eventually of global capitalism, Shanghai can also be envisaged as the epicenter of a vast network of Buddhist economic undertakings. Its rapid economic rise in the 1920s and 1930s in the context of a relatively stable sociopolitical situation were some of the key reasons why Buddhist lives could be imagined and Buddhist circles could flourish. ${ }^{10}$ Always a sign of institutional health, Shanghai wealth gave impetus to the foundation of large number of temples. Eminent monks from across China regularly gathered in the city to mobilize patronage, give lectures and take part in proselytizing and instructional activities. ${ }^{11}$ In the course of a few decades, the city made up for its relatively small number of temples: at least one hundred and forty-nine new monasteries and halls were built in Shanghai during the late Qing period and the Republic, some of which are still standing today. For instance, the Yufo Temple 玉佛寺, originally located in Jiangwan 江灣 town, was moved to its current location closer to downtown in 1918. It remains a focus of Shanghai Buddhist life to this day. Before 1949, the city contained at least three hundred Buddhist monasteries staffed by some five thousand clerics. ${ }^{12}$ There were also many shrines in the back alleyway where, in Lu Hanchao's words, '[w]ith the addition of a few religious statues and a table for joss sticks and candles, a living room or wing room of a shikumen could be transformed into a Buddhist temple. ${ }^{13}$

9 See, for example, Goossaert, '1898: The Beginning of the End'.

10 There is a significant amount of literature on Republican Shanghai and financial capitalism in particular. Unfortunately, most of it ignores the role of Buddhism. See, for instance, Yeh, Shanghai Splendor; Wakeman and Yeh, eds. Shanghai Sojourners; Ji, A History of Modern Shanghai Banking.

11 For Yinguang, see Kiely, 'Spreading the Dharma'. See also Yinguang, Yinguang fashi wenchao. On Xuyun, see Campo, La construction de la sainteté. On Yinshun, see Tien, A Modern Buddhist Monk-reformer in China; Chu, A Buddha-Shaped Hole. For Hongyi, see Birnbaum, 'Two Turns in the Life of Master Hongyi, 161-208'; Tarocco, The Cultural Practices of Modern Chinese Buddhism.

12 Tarocco, 'The City and the Pagoda'. 
For all its economic exuberance, Shanghai Buddhism was not merely an elite phenomenon. Importantly, Buddhism generated new urban subjectivities. Buddhist calendrical rituals and fairs attracted huge crowds. The numerous temples and market fairs encapsulated the religious-economic logic of Jiangnan. Workers in the cotton mills used Buddhist temples to formalize the creation of 'sisterhood societies' (jiemeibui 姊妹會), which helped them cope with the brutal working conditions of factories. In fact, when Communist activists wanted to access the sisterhoods, they had to worship at Buddhist temples with the members, kneel and burn incense and make pledges in front of a Buddhist altar. ${ }^{14}$

The very wealthy were also interested in Buddhism. The Shanghai tycoon, Silas Hardoon, one of Shanghai's richest men, funded the construction of Aili Gardens together with his pious Buddhist wife Luo Jialin. The Hardoons building extravaganza project took five years to build. It extended over $171 m u$ 畧 (about eleven hectares) and contained eight scenic spots of Buddhist inspiration, a college, a number of traditional schools, pavilions, pagodas, a stone boat, a theatre, an artificial stream, a lake and several ponds. Aili Gardens merged the setting of the traditional scholar's landscape garden (yuanlin 園林) with an array of Buddhist-inspired modern facilities, including the so-called Kalavinka Hermitage. ${ }^{15}$ The renowned scholar-monk Zongyang 宗仰 (1861-1921) lived there since 1908 and worked on the publication of the Buddhist Canon, a costly merit-making endeavor that was supported by the Hardoons. ${ }^{16} \mathrm{~A}$ second monk, Yuexia 月霞 (1858-1917), had more than eighty young clerics study with him at Huayan University 華嚴大學, the seminary located inside the villa. By 1945, according to the statistics of the Shanghai Buddhist Society, the number of temples large and small had signifi-

\footnotetext{
13 Lu, Beyond the Neon Lights,185; You, Shanghai jindai; Pan, Shanghai fosi, 42-44.

14 Honig, 'Burning Incense', 712.

15 Pan, Shanghai fosi, 42-44; Lu, Beyond the Neon Lights, 56; You, Shanghai jindai, 136-37. Betta, 'Silas Aaron Hardoon and Cross-Cultural'.

16 See Scott, 'The 1913 Pinjia Canon'.
} 
cantly increased: there were more than five thousand clerics and more than three hundred temples. ${ }^{17}$ Shanghai was also home to dozens of Buddhist charities and lay associations including the Shanghai Buddhist Pure Karma Society (Shanghai fojiao jingyeshe 上海佛教淨業 社) and the Bodhi Study Society (Puti xiehui 菩提協會). The former also ran an orphanage and a clinic. ${ }^{18}$

Shanghai Buddhists were avid consumers of religious goods. Both private initiative and private capital drive Buddhist laity and clerics, often functioning apart from mainstream organizations, to play a greater role in the production of imagery and other piously coded objects. ${ }^{19}$ In the 1930 s, the climate of heightened religious competition contributed to stimulate the emergence of a new type of communication tool in the form of illustrated Buddhist periodicals. I suggested elsewhere that when Chinese Buddhists became conversant with internationally circulated discourses and practices regarding modern media, the technologies involved allowed them to adapted these to local circumstances and generate local meanings..$^{20}$ Buddhist periodicals, of which there were many, were published in relatively small numbers but had a great impact on several Buddhist communities. ${ }^{21}$ Beyond the circulation of religious resources, Chinese Buddhist periodicals laid down the national infrastructure that allowed for the flow of money for nonreligious purposes in novel ways. The wealthy business classes that developed in these communities were patrons of Buddhism and philanthropists. They too engaged in a frenzy of construction of monasteries and Buddhist buildings that has few precedents in history. At the forefront of many of these activities were charismatic clerics who were active fundraisers.

Chinese Buddhist activists and entrepreneurs followed a more-orless loose collection of ideas and practices spread over several Chinese localities. Men and women who identified as Buddhists enjoyed

\footnotetext{
17 You, Shanghai jindai,136-37; Tarocco, The Cultural Practices.

18 Chen, Fojiao honghua, 58-61.

19 Tarocco, 'On the Market'.

20 Tarocco, 'On the Market'; Tarocco, 'The Wailing Arhats'.

21 Kiely, 'Spreading the Dharma'; Scott, 'Revolution of Ink'.
} 
novel modes of cultural production and consumption. ${ }^{22}$ In 1950s, according to Holmes Welch, most Shanghai-based lay Buddhist groups 'dropped out of sight', even if the city still enjoyed the highest level of freedom and support for Buddhist activities of anywhere in China. ${ }^{23}$ No religious practices could be performed outside officially sanctioned premises, whose number was comparatively quite small. This is still the case today.

\section{Tourism and Philanthropy}

Like most urban temples, those in Shanghai were shut down during the Cultural Revolution. One of the most important sites, Jing'an Temple 靜安寺, was locked up by the People's Liberation Army in the mid-1960s, presumably to stave off attacks by the Red Guards who had significantly damaged religious buildings and ritual paraphernalia at the beginning of the Cultural Revolution, when religious images were 'struggled against'. ${ }^{24}$ According to Denise Ho's research on the activities of the Shanghai cultural bureaucracy during the Cultural Revolution and the Maoist campaigns to 'destroy the four olds' (po sijiu 破四舊), Buddhist property suffered significant damage. She writes that 'Much of the destruction was neither preempted nor prevented: at the Chenxiang Pavilion 沉香閣 all the Buddhas were destroyed, the Jing'an Temple lost all its cultural relics, the thousands of volumes of scripture at the Longhua Temple were burned. ${ }^{25}$ Given the extent of the devastation, the recovery underway is notable. The State Administration for Religious Affairs

\footnotetext{
22 Jessup, The Householder Elite; Tarocco, 'On the Market'.

23 Welch, Buddhism Under Mao, 317.

24 Welch, 348.

25 Ho, 'Revolutionizing Antiquity', 692. For an account of the destruction at Longhua Temple see also Jin, 'Budao de Longhua ta'. During the restoration of the temple in the early 1982, the clerics received a Qing dynasty bell and other ritual objects and icons from other monasteries in the Shanghai metropolitan area. See Di, 'From Trash to Treasure'.
} 
(SARA) was set up to interact with religious clergy and laypeople and to facilitate the promotion of religious sites as ideal tourist attractions. Crucially, SARA's duties also include: 'educating religious adherents in Marxism, mobilizing them toward state goals, censoring foreign religious publications distributed domestically, monitoring foreign religious visitors in China, and giving foreigners a good impression of religions in China'. ${ }^{26}$ These fairly antithetical goals do not prevent the state from providing funding for the reconstruction and expansion of some of China's Buddhist temples. A good example of this is Nanputuo Temple 南普陀寺, whose reconstruction was subsidized by the state as well as by substantial donations from overseas Chinese. The donations enabled the monks to expand and repair several other of Xiamen's smaller temples. While overseeing the economic organization of the temples, the government takes away a portion of their revenue. Some of this income is reinvested in the temples' renovation and expansion but a chunk of it is spent outside, thus generating profound disagreements between Buddhists and local authorities. Clerics object to having to give away a portion of their money to pay for salaries and other petty expenses. Monks feel forced to contribute to the market economy in ways that are contrary to the interests of the Buddhist community. ${ }^{27}$ Even though the local government's reasons for involvement in the affairs of Buddhist temples is not necessarily to ensure Buddhism's survival in China nor to give them a means of proselytizing, the money and opportunities tourism provides do go some way towards achieving this. Buddhism and the state are involved in a complex relationship: a game in which each must take the other into account and where the interests of one sometimes require it first to work for the interests of the other.

During my fieldwork in Shanghai in the 1990s, I witnessed many instances in which clerics successfully re-established channels of patronage and engaged new donors. ${ }^{28}$ Philanthropy and building

26 Ashiwa and Wank, 'The Politics of Reviving a Buddhist Temple', 343-44; Ashiwa, 'Dynamics of the Buddhist revival movement', 23

27 Ashiwa and Wank, 'The Politics of Reviving a Buddhist Temple'.

28 In September and October 1998, I talked to Feng Yiyin 豐一吟 and Liu 
projects have in fact emerged as two possible arenas of Buddhist intervention. Personal initiative is significant because the recuperation of temples was initially supposed to be limited to those that were used for religious activities immediately before the Cultural Revolution. The rest, if not occupied for other purposes, was to be reconfigured as a tourist site. In 1991, a new set of regulations specified that opening a religious site needed to be approved by county- or higher-level government authorities. The assumption was then that the existing number of religious sites was already sufficient to meet demand. ${ }^{29}$ Ultimately, economic development, tourism, historical heritage, and cultural nationalism are the common grounds for the state to compromise with local groups seeking to rebuild temples or revive local religious rituals.

The unleashing of market forces in the real estate sector has, to some extent, supported the survival of a few Buddhist sites in Shanghai. Local authorities attempt to derive legitimacy by claiming continuity with the past. They also compete with practitioners in claiming to be the rightful custodians of Buddhism's historical heritage. The case of Jing'an Temple is quite striking in this respect. After the end of the Cultural Revolution, in 1983, it was designated as a key national Buddhist site. In 1984, the city government donated the equivalent of three hundred thousand dollars to the Temple Restoration Committee. The first phase of its restoration was completed in 1990, followed by successive ever more lavish interventions. During our interviews, practitioners and temple volunteers eagerly explained that local and international donors had committed huge sums and that the new halls were built with expensive timber imported from Myanmar. The main hall of Jing'an Temple now hosts a fifteen-ton silver Guanyin statue that 'was rescued by a Chinese businessman' from its previous location, where it had weathered and cracked. Not only did the donor sponsor the thorough restoration of the icon but

Xueyang 劉學樣, the daughter and son of two prominent Republican-period Shanghai lay Buddhists, and to three monks at Longhua and Yufo Temples who wished to remain anonymous.

29 Goossaert and Palmer, The Religious Question. 
he also underwrote the construction of the area of the temple where it is now enshrined. ${ }^{30}$ Today, Jing'an temple lies at the center of one of Shanghai's richest neighborhood. And while it remains a ritual space activated by worship, the boundaries between the temple and the museum are often unclear. ${ }^{31}$

Maintaining control over economic resources generated by tourism and donations is a persistent challenge for Chinese Buddhist clerics. The powerful lay Buddhist who headed the Buddhist Association of China for decades, Zhao Puchu 趙樸初 (1907-2000), who hailed from Shanghai, was to a certain extent instrumental in helping Buddhists reclaim the governance of their temples and hold on to some of the funds they received from donations. He was also one of the decision makers involved in the construction of the large Buddha statue of Lingshan. The site attracts tourists and pilgrims and charges them a substantial entrance fee. Once again, while a sizeable part of this money goes to the para-governmental company that built the site, the monks can keep the offers in the donation boxes. ${ }^{32}$

As the domestic tourism market continues to grow, Buddhists are forced to run the risk of being overwhelmed by it. Under the logic of late capitalism, the packaging of cities as commodities and the demands for a unique cultural experience associated with a specific place and its built environment are central to the tourist imagination. In fact, the regulation of religious sites and their designation as tourist sites is meant to mobilize and manage a growing wealthy population. Local authorities have exploited the vernacular built

30 Interviews conducted at Jing'an in October 2014 and November 2015. The Temple was one of the first ones in China to have a website and to actively fundraise, see 'Jing'an si', accessed May 14, 2018, http://www.shjas.org/.

31 'Tarocco, 'The City and the Pagoda'; cf. Alsayyad, Consuming Tradition. For China see Oakes, Tourism and Modernity in China; Oakes and Sutton, eds., Faiths on Display. For the manufacturing of novel pilgrimage sites associated with the CCP, see Wagner, 'Reading the Chairman Mao'.

32 For Lingshan charitable activities, see http://www.lingshanfoundation. org/index.php. 
heritage to attract investment from China, Hong Kong and Singapore. And yet, Buddhist clerics and other practitioners do attempt to retain some control over the development of the religious/tourism complex.

The charismatic abbot of a small temple in Ningbo has ambitious plans to build three more monastic and pilgrimage sites. Promotional materials, videos and photographs, portray him wearing a builder's helmet and breaking ground on a construction site. He tells me of his relationship with wealthy Shanghai donors and of his efforts to restore his temple and build new ones. Many others like him have adopted a pragmatic and dynamic approach to the market forces that drive contemporary Chinese life. ${ }^{33}$

In Brooks Jessup's analysis of its genesis in 1920s Shanghai, the World Buddhist Householder Grove, a lay organization, created a novel space for participation in Buddhist life by trying to unify a number of pre-existing ritual practices as well as promoting new ones. Lay Buddhists sought to institutionalize charity work including flood relief, the running of soup kitchens, and the establishment of schools. They also launched the publishing house Shanghai Buddhist Books, a joint stock limited-liability corporation that, while run for profit, was solely dedicated to spreading the teachings of Buddhism through the production of Buddhist goods. ${ }^{34}$ They also produced all manner of religious paraphernalia, recorded gramophone records of Buddhist chants and sermons, and began to run a Buddhist radio station. ${ }^{35}$ In the post-Mao period, Shanghai-based clerics again were at the forefront of charitable activities. The abbot of the Jade Buddha Temple, Zhenchan 真禅, made donations to the Children's Welfare Association since 1984, and eventually founded the Master Zhenchan Children's Welfare Foundation. In 2008, the temple finally established a charitable foundation, the Juequn

33 Interview with C., May 13, 2017, Ningbo. See also Ashiwa and Wank, 'The Politics of Reviving Buddhist Temple'. Cf. for example, Chan and Lang, 'Temples as Enterprises'.

34 Jessup, The Householder Elite.

35 Tarocco, The Cultural Practices, 129. 
Ci’ai Gongdehui 覺群慈愛功德會. ${ }^{36}$ Yet another Jiangnan-based organization, the Lingshan Compassion Foundation (Lingshan Cishan Jijinhui 靈山慈善基金會), which is connected with the large Buddha statue mentioned earlier, explicitly modeled itself after the Taiwan-based Tzu Chi Buddhist Foundation whose founder, the charismatic nun Cheng Yen 證嚴, established The Bamboo Bank to manage revenue from donations. Nowadays, her followers donate money in an even more straightforward way using an application linked to their credit card. Besides facilitating donations, the app gives access to edifying life stories and a compilation of the aphorisms. ${ }^{37}$

In Shanghai, urban planners of the Xuhui District have decided to build the vast real estate development and visual arts hub called West Bund (Xian 西岸) near one of the city's oldest Buddhist sites, the Longhua Temple. It still remains to be seen how the Longhua area will develop and what role, if any, Buddhist practitioners will be able to play in the current reshaping of the monastic complex. ${ }^{38}$ This is only one of many examples of the promotion of a religious site for tourism via the use of grandiose architecture. Arguably, its case is both exceptional and typical of today's China. Temples are one and the same time-but possibly not for the same people-objects of aesthetic admiration as well as of devotion, of religious empowerment, leisure and consumption. In some Buddhist sites, the use of exhibitory space as part of the circuit of pilgrimage and worship indicates broader trends in the changing role of museums and the peculiar museum mode of display and enshrinement. The blurring of the

36 See 'Juequn ci'ai jiayuan' 覺群慈愛家園, accessed June 2018, http://juequn. com/guanyuwomen/juequnciaijiayuan/. For a history of charitable activities in China during the Ming and Qing periods, see Smith, The Art of Doing Good.

37 See 'The Bamboo Bank: No Good Deed Is Too Small', accessed September 12, 2015, http://www.tzuchi.us/blog/bamboo-bank/; Huang, Charisma and Compassion.

38 For Longhua Temple, see http://www.longhua.org/ and for West Bund see 'Location', accessed June 13, 2018, http://www.westbund.com/en/index/ VISITORSS-GUIDE/Location/Location.html. The interviews with local urban planners, conducted in 2014, are in my personal archive. 
boundary between museum and temple is emblematic of the shift of key cultural institutions in response to the new 'cultural economy' that scholars should begin to acknowledge. Inevitably, as organized religions undergo profound changes, the religious institutions that they build must be designed to perform new tasks, to address unfamiliar audiences as well as consolidate their existing constituencies, to make new claims as well as repeat older messages. In China, this leads to a new kind of religious institution that combines ancient symbols and modern communication technologies. Nowhere is that more clearly visible than in some of the new sites of Shanghai and Jiangnan Buddhism. A reconfigured, architecturally grandiose form is used to reinforce traditional soteriological claims. It also produces a different kind of space in the context of China's secular and mostly hostile state. The temple/museum or the temple/theme park is emerging in twenty-first century China as one of the key cultural forms through which both religious revivalism and cultural nationalism attempt to consolidate their statements and constituencies. And this, in turn, suggests that the opposition between the realm of the sacred and that of the secular, rational and modern space of the museum, a distinction common to the understanding of museum formation in Europe, is a conceptual structure that no longer meets the theoretical challenges of today's events. In late socialist China since the early 1980s, the revival of religion, commercial developments, and tourism have advanced in parallel-but their interrelationship is still quite hard to grasp. China's relative decentralization has produced varied and somewhat inconsistent official and grassroots initiatives.

\section{Buddhism and the Chinese Digital Age}

Mediation through or with material objects is crucial to the practice of Chinese Buddhism. Unique in the modern and postindustrial eras is the fact that such mediation can be highly personal and readily accessible to larger and larger audiences. The multiplication and diversification of the goods that are produced and consumed and of the motivations of those that produce and consume them further complicates any attempts at easy generalization. The production, worship 
and veneration of empowered objects, the ritual uttering of magic formulas and chanting of scriptures have always been and still are key Buddhist practices, even before modern technologies and travel allowed for their seemingly endless multiplication. In the Chinese digital age, with its unprecedented amounts of economic power at the individual level, choices in Buddhist religious consumption will grow all the more important and can potentially transform how the religious and the sacred are experienced. Buddhist-inspired religious practices will need to be understood in more holistic and fluid ways than the religious economy model can afford. Chinese Buddhism displays a vibrant religious goods culture. Internet-based outlets have embraced the rules of globalization and e-commerce alongside more traditional forms of charity and fund-raising. ${ }^{39} \mathrm{CDs}$ and other digital objects are viewed as forms of spiritual emanation of the charisma of a Buddhist cleric. ${ }^{40}$ Modern religious consumers engage with a plethora of piously coded objects marketed in an ever-shifting landscape of faith, ritual action and consumption. Charisma and efficacy (ling 靈) find new ways to infuse themselves into mass-produced artifacts. For instance, the electronic radio-like device nianfoji 念佛機 that reproduces Buddhist chants has become increasingly more popular over the past three decades and is now conspicuously displayed in public spaces within temples. ${ }^{41}$ This piously-coded object together with many other Buddhist-inspired commodities defy discrete conceptions of piety and consumption. Ultimately, twenty-first-century Chinese Buddhist life is remarkable because its widespread charismatic paradigms are increasingly more visible vis-à-vis an atheist party-state and the logic of market capitalism.

39 For the marketing religious goods online, see for instance http://ltc.bailinsi.net/big_class.lq?bid=40, accessed 12 June 2018. For the list of the names of donors and the sum they have offered in the meritorious names' section (gongde fangming 功德芳名), see http://ltc.bailinsi.net/news_show.lq?id=45, accessed 12 June 2018.

40 See the sources underlying Tarocco, 'Technologies of Salvation'.

41 See Heller, 'Buddha in a Box'. 


\section{Bibliography}

Alsayyad, N., ed. Consuming Tradition, Manufacturing Heritage: Global Norms and Urban Forms in the Age of Tourism. London: Routledge, 2001.

Ashiwa, Yoshiko. 'Dynamics of the Buddhist revival movement in South China: State, Society, and Transnationalism'. Hitotsubashi Journal of Social Studies 32 (2000): 15-31.

Ashiwa, Y., and L. D. Wank. 'The Politics of Reviving a Buddhist Temple: State, Association, and Religion in Southeast China'. The Journal of Asian Studies 65, no. 2 (2006): 337-59.

Betta, Chiara. 'Marginal Westerners in Shanghai: The Baghdadi Jewish community, 1845-1931'. In New Frontiers: Imperialism's New Communities in East Asia, 1842-1953, edited by Robert A. Bickers and Christian Henriot, 38-54. Manchester and New York: Manchester University Press and St. Martin's Press, 2000.

- - - 'Silas Aaron Hardoon and Cross-Cultural Adaptation in Shanghai'. In The Jews of China, volume 1, edited by Jonathan Goldstein, 216-29. Armonk: M.E. Sharpe, 1999. Bingenheimer, Marcus. Island of Guanyin: Mount Putuo and Its Gazetteers. Oxford: Oxford University Press, 2016.

Birnbaum, Raoul. 'The Deathbed Image of Master Hongyi'. In The Buddhist Dead: Practices, Discourses, Representations, edited by Bryan J. Cuevas and Jacqueline I. Stone, 175-207. Honolulu: University of Hawai'i Press, 2007.

- - - 'Master Hongyi Looks Back. A Modern Man Becomes a Monk in Twentieth-Century China'. In Buddhism in the Modern World: Adaptations of an Ancient Tradition, edited by Steven Heine and Charles Prebish, 75-124. Oxford: Oxford University Press, 2003.

- - - 'Two Turns in the Life of Master Hongyi, a Buddhist Monk in Twentieth-Century China'. In Making Saints in Modern China, edited by David Ownby, Vincent Goossaert and Ji Zhe, 161-208. Oxford: Oxford University Press, 2016.

Brook, T. Praying for Power: Buddhism and the Formation of Gentry Society in Late Ming China. Cambridge: Harvard University Press, 1993. 
- - - 'Xu Guangqi and His Context: The World of the Shanghai Gentry'. In Statecraft and Intellectual Renewal in Late Ming China: The Cross-Cultural Synthesis of Xu Guangqi (1562-1633), edited by Catherine Jami, Peter Mark Engelfriet and Gregory Blue, 72-98. Leiden: Brill, 2001.

Campo, Daniela. La construction de la sainteté dans la Chine moderne: la vie du maitre bouddhiste Xuyun [The creation of sainthood in modern China: The life of Buddhist Master Xuyun]. Paris: Les Belles Lettres, 2013.

Carter, James. Heart of Buddha, Heart of China: The Life of Tanxu, a Twentieth-Century Monk. Oxford: Oxford University Press, 2011.

Cen Xuelü 岑學呂. Xuyun fashi nianpu 虛雲法師年譜 [Chronicle of the Life of Master Xuyun]. Beijing: Zongjiao wenhua chubanshe 宗教文化出版社, 1995 reprint.

Chan, Selina Ching, and Graeme Lang. 'Temples as Enterprises'. In Religion in Contemporary China: Revitalization and Innovation, edited by Adam Yuet Chau, 133-53. New York: Routledge, 2011.

Chen Bing 陳兵, and Deng Zimei 鄧子美. Ershi shiji Zhongguo fojiao 二十世紀中國佛教 [Chinese Buddhism in the Twentieth Century]. Beijing: Minzu chubanshe 民族出版社, 2000.

Chen Yongge 陳永革. Fojiao honghua de xiandai zhuanxing: Minguo Zhejiang fojiao yanjiu, 1912-1949 佛敉弘化的現代轉型: 民國 浙江佛敎研究, 1912-1949 [The Modern Transformation of Buddhist Propagation: A Study on Buddhism in Zhejiang during the Republican Period]. Beijing: Zongjiao wenhua chubanshe 宗 教文化出版社, 2003.

Chu, William P. A Buddha-Shaped Hole: Yinshun's 印順 (19062005) Critical Buddhology and the Theological Crisis in Modern Chinese Buddhism. Ph.D. dissertation, University of California, Los Angeles, 2006.

Di Yin Lu. 'From Trash to Treasure: Salvage Archeology in The People's Republic of China, 1951-1976'. Modern China 42, no. 4 (2016): 415-43.

Dietrich, Craig. 'Cotton Culture and Manufacture in Early Ch'ing China'. In Economic Organization in Chinese Society, edited by 
W. E. Willmont, 109-35. Stanford: Stanford University Press, 1972.

Dunstan, Helen. State or Merchant? Political Economy and Political Process in 1740s China. Cambridge: Harvard University Asia Center, 2006.

Elvin, Mark. 'Market Towns and Waterways: The County of Shanghai from 1480 to 1910'. In The City in Late Imperial China, edited by G. W. Skinner, 441-73. Stanford: Stanford University Press, 1977.

Fan Jinmin 范金民. Ming QingJiangnan shangye de fazhan 明清江 南商業的發展 [Commercial Development in Jiangnan during the Ming and Qing dynasties]. Nanjing: Nanjing daxue chubanshe 南京大學出版社, 1998.

- — - 'Qingdai Jiangnan mianbu zihao tanxi' 清代江南棉布字 號探析 [Analysis of the Cotton Industries in the Qing dynasty Jiangnan]. Lishi yanjiu 歷史研究 [Historical Studies] 1 (2002): 88-98.

Goldfuss, Gabriele. Vers un Bouddhisme du XX'e siècle. Yang Wenhui (1837-1911), réformateur lä̈que et imprimeur [Toward a Twentieth Century Buddhism: Yang Wenhui (1837-1911), Lay Reformer and Printer]. Paris: Collège de France, Institut des Hautes Études Chinoises, 2001.

Goossaert, Vincent. '1898: The Beginning of the End for Chinese Religion?'. Journal of Asian Studies 65, no. 2 (2006): 307-36.

- _ . 'Anatomie d'un discours anticlérical: le Shenbao, 1872-

1878 ' [Anatomy of an anti-cleric discourse: the Shenbao, 18721878]. Extrême-Orient, Extrême-Occident [Far East, Far West] 24 (2002): 113-31.

- - D Dans les temples de la Chine: Histoire des cultes, Vie des communautés [In the temples of China : History of cults, life of communities]. Paris: Albin Michel, 2000.

- - - 'Republican Church Engineering. The National Religious Associations in 1912 China'. In Chinese Religiosities: Affictions of Modernity and State Formation, edited by Mei-hui Yang Mayfair, 209-32. Berkeley: University of California Press, 2008. - - - 'Starved of Resources: Clerical Hunger and Enclosures in Nineteenth-Century China'. Harvard Journal of Asiatic Studies 
62, no 1 (2002): 77-133.

- _ - 'State and Religion in Modern China: Religious Policies and Scholarly Paradigms'. Paper presented for the Panel 'State and Society' at Rethinking Modern Chinese History: An International Conference to Celebrate the 50th Anniversary of the Institute of Modern History, Academia Sinica, Taipei, June 29-July 1, 2005. Goossaert, Vincent, and Palmer David. The Religious Question in Modern China. Chicago: University of Chicago Press, 2011. Fisher, G. 'In the Footsteps of the Tourists: Buddhist Revival at Museum/Temple Sites in Beijing'. Social Compass 58, no 4 (2011): 511-24.

Heller, Natasha. 'Buddha in a Box: The Materiality of Recitation in Contemporary Chinese Buddhism'. Material Religion 10, no. 3 (2014): 294-314.

Ho, D. Y. 'Revolutionizing Antiquity: The Shanghai Cultural Bureaucracy in the Cultural Revolution, 1966-1968'. The China Quarterly 207 (2011): 687-705.

Honig, E. 'Burning Incense, Pledging Sisterhood: Communities of Women Workers in the Shanghai Cotton Mills, 1919-1949'. Signs 10, no. 4 (1985): 700-14.

Huang, Julia, C. Charisma and Compassion: Cheng Yen and the Buddhist Tzu Chi Movement. Cambridge: Harvard University Press, 2009.

Jessup, James Brooks. The Householder Elite: Buddhist Activism in Shanghai, 1920-1956. Ph.D. dissertation, University of California, Berkeley, 2010.

Ji Zhaojin. A History of Modern Shanghai Banking: The Rise and Decline of China's Financial Capitalism. London: Routledge, 2016.

Ji Zhe. 'Buddhist Institutional Innovations'. In Modern Chinese Religion II: 1850-2015, edited by Vincent Goossaert, Jan Kiely and John Lagerwey, 731-66. Leiden: Brill, 2016.

Jin Ding 金鼎. 'Budao de Longhua ta' 不倒的龍華塔 [Longhua pagoda that has never been destroyed]. In Shoucang lish $i$ 收藏 歷史 [History of Collections], edited by Chen Pengju 陳鵬舉, 235-37. Shanghai: Shanghai shudian chubanshe 上海書店出版 社, 1998. 
Johnson, Linda Cooke, ed. Cities of Jiangnan in Late Imperial China. Albany: State University of New York Press, 1993.

- - - Shanghai: From Market Town to Treaty Port, 1074-1858. Stanford: Stanford University Press, 1995.

Kiely, J. 'Spreading the Dharma with the Mechanized Press:

New Buddhist Print Cultures in the Modern Chinese Print Revolution, 1866-1949'. In From Woodblocks to the Internet: Chinese Publishing and Print Culture in Transition, 1800-2008, edited by Christopher Reed and Cynthia Brokaw, 185-210. Leiden: Brill, 2010.

Li Bozhong. Agricultural Development in Jiangnan, 1620-1850. New York: St. Martin's Press, 1998.

Lu Hanchao. Beyond the Neon Lights: Everyday Shanghai in the Early Twentieth Century. Berkeley: University of California Press, 1999.

Naquin, S. Peking: Temples and City Life, 1400-1900. Berkeley: University of California Press, 2000.

Nedostup, Rebecca. Superstitious Regimes: Religion and the Politics of Chinese Modernity. Cambridge: Harvard University Asia Center, 2009.

Oakes, Tim. Tourism and Modernity in China. New York: Routledge, 1998.

Oakes, Tim, and Donald S. Sutton, eds. Faiths on Display: Religion Tourism, and the Chinese State. Lanham: Rowman and Littlefield Publishers, 2010.

Pan Mingquan 潘明權. Shanghai Fosi daoguan 上海佛寺道觀 [Buddhist and Daoist Temples in Shanghai]. Shanghai: Shanghai cishu chubanshe 上海辭書出版社, 2003.

Potter, P. B. 'Belief in control: Regulation of religion in China'. The China Quarterly 174, no. 1 (2003): 317-37.

Pittman, Don A. Toward a Modern Chinese Buddhism: Taixu's Reforms. Honolulu: University of Hawai'i Press, 2001.

Ritzinger, Justin R. Anarchy in the Pure Land: Tradition, Modernity, and the Reinvention of the Cult of Maitreya in Republican China. Ph.D. dissertation, Harvard University, 2010.

Ruan, Renze 阮仁澤, and Gao Zhennong 高振農 eds. Shanghai zongjiao shi 上海宗教史 [History of the Religions in Shanghai]. 
Shanghai: Shanghai renmin chubanshe 上海人民出版社, 1992. Scott, Gregory A. 'The 1913 Pinjia Canon and the Changing Role of the Buddhist Canon in Modern China'. In Reinventing the Tripitaka: Transformation of the Buddhist Canon in Modern East Asia, edited by Jiang Wu and Greg Wilkinson, 95-125. Lexington Books, 2017.

- - _. 'Absolutely Not a Business: Chinese Buddhist Scriptural Presses and Distributors, 1860s-1930s'. KODEX-Jabrbuch der $I B G$ [Codex: Yearbook of the International Society for Book Science] 6 (2016): 67-82.

- - Conversion by the Book: Buddhist Print Culture in Early Republican China. Ph.D. dissertation, Columbia University, 2013.

- _ - 'Revolution of Ink: Chinese Buddhist Periodicals in the Early Republic'. In Recovering Buddhism in Modern China, edited by Jan Kiely and J. Brooks Jessup, 111-40. New York: Columbia University Press, 2016.

- - - 'Survey of Religious Reconstruction in Modern China'. Harvard Dataverse. Last updated August 23, 2016. http:// dx.doi.org/10.7910/DVN/ZKT6EJ.

Smith, Joanna Handlin. The Art of Doing Good. Cambridge: Harvard University Press, 2007.

Tarocco, Francesca. 'The City and the Pagoda: Buddhist Spatial Tactics in Shanghai'. In Handbook of Religion and the Asian City: Aspirations and Urbanization in the Twenty-first Century, edited by Peter van der Veer, 37-51. Berkeley: University of California Press, 2015.

- - - The Cultural Practices of Modern Chinese Buddhism: Attuning the Dharma. Abingdon and New York: Routledge, 2007.

- - . ' On the Market: Consumption and Material Culture in Modern Chinese Buddhism’. Religion 41, no. 4 (2011): 627-44.

- - - 'Technologies of Salvation: (Re)locating Chinese Buddhism in the Digital Age'. Journal of Global Buddhism 18 (2017): 155-175.

- - - 'The Wailing Arhats: Buddhism, Photography and Resistance in Modern China'. In The Art of Merit: Studies in 
Buddhist Art and its Conservation, edited by David Park and Kuenga Wangmo, 113-23. London: Archetype Publications, 2014.

ter Haar, B. 'Buddhist-inspired Options: Aspects of Lay Religious

Life in the Lower Yangzi from 1100 until 1340'. T'oung Pao 87 (2001): 92-152.

Tien, Po-yao. A Modern Buddhist Monk-reformer in China: The Life and Thought of Yin-shun. Ph.D. dissertation, California Institute of Integral Studies, 1995.

Wakeman, Frederic Jr., and Wen-hsin Yeh, eds. Shanghai Sojourners. Berkeley: University of California Berkeley Institute of East Asian Studies, 1992.

Wagner, Rudolf G. 'Reading the Chairman Mao Memorial Hall in Peking: The Tribulations of the Implied Pilgrim'. In Pilgrims and Sacred Sites in China, edited by Susan Naquin and Chünfang Yü, 378-423. Berkeley: University of California Press, 1989.

Walsh, Michael. Sacred Economies: Buddhist Monasticism and Territoriality in Medieval China. New York: Columbia University Press, 2010.

Welch, H. 'The Buddhist Career'. The Journal of the Hong Kong Branch of the Royal Asiatic Society 2(1962): 37-48.

- - . The Buddhist Revival in China. Cambridge: Harvard University Press, 1968.

-_- Buddhism Under Mao. Cambridge: Harvard University Press, 1972.

- - . The Practice of Chinese Buddhism 1900-1950. Cambridge: Harvard University Press, 1967.

- - - 'The Reinterpretation of Chinese Buddhism'. China Quarterly 22 (1965): 143-53.

Wu Jiang. Enlightenment in Dispute: The Reinvention of Chan Buddhism in Seventeenth-Century China. Oxford: Oxford University Press, 2008.

Xue, Yu. Buddhism, War, and Nationalism: Chinese Monks in the Struggle against Japanese Aggressions, 1931-1945. New York: Routledge, 2005.

Yang, Lien-sheng. 'Buddhist Monasteries and Four Money-raising Institutions in Chinese History'. Harvard Journal of Asiatic 
Studies 13, no. 1-2 (1950): 174-91.

Yeh, Wen-hsin. Shanghai Splendor: Economic Sentiments and the Making of Modern China, 1843-1949. Berkeley: University of California Press, 2007.

Yinguang 印光. Yinguang fashi wenchao 印光法師文抄 [Selections of the Writings of Master Yinguang], 3 volumes. Beijing: Zongjiao wenhua chubanshe 宗教文化出版社, 2000.

You, Youwei 游有維. Shanghai jindai fojiao jianshi 上海近代佛 教簡史 [A Brief History of Buddhism in Modern Shanghai]. Shanghai: Huadong shifan daxue chubanshe 華東師範大學出版 社, 1988. 